\title{
Twenty years of evolution in the Church's thinking about communications
}

\author{
von Robert A. White, S.J.*
}

„Aetatis Novae“ is presented as a commemoration of twenty years since Communio et Progressio, and it takes as its starting point the theological framework of Communio et Progressio. "Aetatis Novae" announces itself as a document quite modest in comparison with its predecessor. There is little of the sweeping theological vistas, comprehensive public philosophy of media, and landmark guidelines of ecclesial communication outlined in Communio et Progressio (CP). In this pastoral instruction, the leaders of the Pontifical Council for Social Communication ,simply wish to provide a working tool and a measure of encouragement to those confronting the pastoral implications of the new realities of (social communication)" 1 The tone of „Aetatis Novae" is more tentative, preferring to outline themes for further reflection and discussion in the local church rather than provide definitive answers.

The major and central recommendation of "Aetatis Novae" is that social communications be made an integral part of the pastoral planning of the diocese, the regions and national episcopal conferences. The most concrete set of actions encouraged are listed in a set of guidelines, „Elements of a Pastoral Plan for Social Communications“. Although these are termed an appendix, one has the impression that these are perhaps the central message of "Aetatis Novae". Indeed, the message is coming through "loud and clear": although Communio et Progressio provided us with a beautiful, idealistic vision of communication in our societies and in the church, at the level of the typical diocese and parish there has often been little action. The Catholic Church, in comparison with other religious groups, still has not put a new era of communications to work to communicate the gospel both within ecclesial communities and to the society around it.

Although all pastoral instructions are written in a particular way for the bishops, „Aetatis Novae“ specifically asks bishops to take action. Perhaps there is the feeling that bishops tend to ignore complex speculative documents, but they are more likely to respond to shorter documents that outline rather concrete lines of action. Underlying this is a presupposition that if bishops, with the leaders of their dioceses, begin to contemplate concrete actions, they will have to take notice of the changing patterns of communication around them, how these changing patterns are affecting values and how we need to change the way the church communicates. Action tends raise questions of „criteria“, „objectives“ and the „why“, bringing to the surface latent-often conflicting-theological presuppositions that must be clarified. In short, in the process of action, often of a more exploratory nature to begin with, there is likely to emerge a consensual vision that may later provide the basis for a more definitive document.

Prof. Dr. Robert A. White S.J. ist Direktor des ,Centro Interdisciplinare sulla Comunicazione Sociale' an der Pontificia Universita Gregoriana in Rom. 
For many, who would like to see a penetrating theological reflection on what they see as a significant shift in our civilization, this emphasis on the details of pastoral planning in the local church may seem to be an anticlimax. "Is this all that we can say", could be a not untypical disappointed reaction. But perhaps "Aetatis Novae" reflects the fact that we do not have much consensus now on what we want to say.

It would be a mistake, however, to dismiss „Aetatis Novae“ as unimportant because, I would suggest, the emphasis on pastoral planning reflects quite accurately many of the major shifts of thought over the past twenty years among those involved with the communication activities of the Church throughout the world.

Underlying this shift of perspective in the Church are major technological, political-economic, and cultural changes in the realm of social communications. Also intervening is the „crisis“, beginning in the late 1960 s, of our fundamental understanding of communication inWestern societies, a crisis that challenged conceptions of communication relatively unchanged since Aristotle. ${ }^{2}$ Especially affected by this "crisis“ were idealistic people in the churches, in education and in social services. ${ }^{3}$ Another important shift is the emerging importance of the „New Churches“ of Africa, Asia and Latin America in the „New Nations“, often with a very different understanding of "social“ communications than that typical of the thought of the "Old Churches" in the industrialized nations at the end of the 1960 s.

If the Catholic Church is to take "Aetatis Novae“ seriously and begin a process of reflection in the process of action at the level of the local church, it may be helpful to begin with an examination of the major shifts and trends over the last twenty years, the "signs of our times" that we must see in order to judge and act.

\section{1. . An Expanding Notion of „Social“ Communication}

When $C P$ was being formulated in the late 1960 s, social communications still meant, most typically, the „mass media“: a centralized broadcasting system covering a nation or a newspaper serving the nation or at least a larger metropolitan area with its hinterland. Broadcasting was defined as a social responsibility, organized by the government as a public service like the postal service, or, if commercial, carefully regulated with public service guidelines. The press, too, was increasingly bathed in an aura as a sacred national institution defending liberal democracy with a high sense of professional honor, based on claims to be"the fourth estate“, the „watchdog" against abuses of power, and the forum for democratic debate. Cinema was widely considering a lower form of popular culture that potentially degraded moral values, but it was rapidly consolidating its position as a major new art form.

Thus, at the time that $C P$ was being formulated, mass communications were at the peak of their reputation as the necessary public forum for debate of socio-political reform, a site for the expression of national cultural and artistic 
traditions, and the template of democratic freedom. By and large the mass media considered religious communication as a form of public service that the churches could take advantage of. The professional media ethics and the social philosophy of public service in the media were sufficiently well formulated by the late 1960 s so that $C P$ could provide an inspiring synthesis of this in Part II and formulate an optimistic theology of media in terms of media as part of God's providential design to bring about true human community and progress. Part III of $C P$ incorporated models of responsible cooperation between the church and broadcasting, press and cinema that pioneers of the church in mass media had developed. The success of the church's work in film clubs suggested ways of educating the faithful to more appreciative and perceptive use of media. And the document of the Second Vatican Council on religious freedom, „Dignitatis Humanae", made it possible for $C P$ to support fully freedom of expression both within the Church and in the larger society.

During the 1970 s and 1980 s, however, there was a widespread retreat from the public service ideal in broadcasting with the "privatization of media" policies. Often this meant that religious broadcasting time, formerly considered a public service, was available only for a price, and it became far more difficult to get air time for religious or educational programming. ${ }^{4}$ In some contexts, the churches have joined other groups in fighting an often losing battle to preserve public service broadcasting. This difficulty has forced the Church-and others interested in educational or other forms of public service programming such as children's programs - to move away from "mass" media to more specialized "narrow" casting such as multi-channel local cable systems or to develop the church's own broadcasting systems. The churches have also been active in supporting the public access, community channels that are available through local or narrow casting.

In many parts of the less-industrialized world, development efforts have given a priority to rapid industrialization, including agricultural industrialization. The rural and urban poor have often been abandoned to their own resources. The Church has made a major commitment to the education of these sectors, especially helping them form an infrastructure of grassroots organizations to defend their rights and form an autonomous base of economic self-help. In these contexts the government directed "public service" media have shown little interest in these marginal, poor groups. Some of the most creative efforts of the church have not been in the "mass" media but in group media, popular theater, local "people's broadcasting stations", or in offset presses under the control of popular movements. The gospel commitment to the poor found some of its truest implementation in media which were anything but "mass" but were nevertheless serving the best ideals of "public service“, social communication.

Where the dominant social communication systems (both broadcasting and press) are commercial, the "mass" media in industrializing countries are often closely linked to the interests of the modernizing elites. The "mass" media have excluded the „public service“ communication efforts of the church and forced the church to develop its own „alternative" media. Efforts to sustain „alternative" media which serve the poor and the less powerful are difficult to 
sustain, however, -especially when this threatens existing structures of power-and one cannot say that they were always given full support by leaders in the Church.

During the 1970 s there was a growing critique of the mass media throughout the world as a communication system that may pretend to be a public service and the watchdog of abuses, but in fact tends to favor the interests of the powerful. This critique initially focussed on the relations between nations (the international flow of information) but increasingly was directed at the concentration of control over media within nations, especially in the less industrially developed nations. This critique suggested that the problems were not just the underdevelopment of communication and information system but the injustice of the systemic „taken-for-granted“ structure of these systems. The world communication system is not an equitable "round table" for harmonious exchange as $C P$ suggested, but rather a table around which sit the information rich, allowing only a few crumbs to accidentally fall to the information poor under the table.

This critique evolved into the now well-known debate over the New World Information and Communication. Although the politics of the NWICO were often complex and contradictory, the goals stated in basic documents such as "The MacBride Report" were essentially to introduce national and international policies embodying many of the ideals enunciated in $C P$. A number of Catholic media professionals and their organizations, especially in the Third World, openly supported the best aims of the NWTCO such as the democratization of services, access and policy making regarding the media. But one of the most disappointing aspects of the debate was that by and large people in the media tended simply to defend their own commercial and narrow professional interests. At both the international and the national level, media interests were able to enlist the support of political power to defeat media reform movements with public service goals.

By the end of the $1980 \mathrm{~s}$, when the time to celebrate 20 years of Communio and Progressio was approaching, the ideals of public service and social responsibility could not be so easily predicated of national media systems. „Aetatis Novae" recognizes this when it includes in a discussion of "social communication" the need for a "critical evaluation of mass media and their impact on culture" (12), with the recognition that "mass media at times ... (shows) ... a lack of concern for the plight of the poor and the neglected" (13). Social communication now includes „alternative media“, "grassroots and traditional media“(16).

Certainly, we must recognize the great achievements of our mass media systems in the face of financial and other constraints. It is wrong to blame all of our social ills on the mass media. ${ }^{5}$ But, with such discouraging results of efforts to implement the ideals of $C P$ in the public media over the last twenty years and the realization now that some of the catch phrases to express social responsibility ideals are covers for the media's own self-serving interests, the hesitance to make another statement with the sweeping optimism of $C P$ regarding the providential role of mass media is not surprising. The consciousness of social sin, unjust structures, and the heroic journalists who suffered and died to give wit- 
ness to the ideals of $C P$ are much closer to the surface. We seem closest to Jesus "the perfect communicator" in his death on the cross.

The church's own media and grassroots communications efforts, which have grown out of efforts in the local church and reflect conscious, „planned“ efforts to explicitly implement the ideals of the gospel in communication have, in the end, come closest to the ideals of $C P$. If we have failed to convince the world of mass media by our beautifully written documents, perhaps we can do more by the concrete witness of the meaning of social communications within the bounds of our own ecclesial communities.

\section{The Shift From "Linear" to "Convergence"/"Communion" Models of Communication and the Close Association of "Communications" with the Development of "Cultures"}

At the time of the formulation of $C P$ the most prevalent conceptions of interpersonal and mediated communication at both academic and common sense language levels were transmission/transport (source-message-channel-receiver-effect-feedback) and rhetorical (persuasion) models. Media studies were still dominated by an mass media model which perceived society as a "market place of ideas" where one had to persuasively sell a message. Media studies everywhere were concerned largely with "effects"-how to get across knowledge, change attitudes and change behavior.

The documents of the Church very wisely moved away from the difficult and controversial term, mass media, and adopted social communications, much closer to the concept of "public“ communication. The „communion“ model of communication proposed by $C P$ reflected a more European, especially British, context of public communication where the media carried on a literary/dramatic/press tradition as a forum for creating, passing on, or critiquing a shared culture. ${ }^{6}$ Surprisingly, however, the communion model of public communication was never picked up, commented on and used to any great extent within Catholic Church circles. In my year's of teaching and discussing $C P$ in seminars with Catholic communicators, I find that virtually all still tend to work with a linear, transport model of communication. The exceptions are those who come from the "New Churches" and who have an experience of the "Communio" model of church embodied in the basic Christian communities.

In contrast to the $1960 \mathrm{~s}$, many communication scholars are today moving toward a conception of communication close to that of $C P$. At the interpersonal level, communication is conceived as the creation of a shared interpretation (meaning) of a situation through interaction and tendency toward a convergence of interpretations that is never complete. ${ }^{7}$ Communication is, thus, not simply the transport of an idea from one to another but an interaction process that creates some new, third meaning somewhat unlike the meanings that the parties originally held. This conception places an emphasis on meaning (culture) and the creative, participatory process of communication. This conception of communication is reflected in the new findings about how broadcast audiences 
almost never passively absorb a message but are actively reinterpreting, resisting, and taking off in entirely unpredictable meaning construction.

At the level of social, public communication, the conceptions of broadcast communication as „communion“ or "public ritual“ (James Carey", Elihu Katz", Michael Real $^{10}$, etc.) or "forum“ (Horace Newcomb") or liminal „communitas"12 are increasingly common. Recently, Latin American scholars, more conscious of the realities of social power in society, tend to propose a model of public communication based on conceptions of hegemony and conflictive cultural negotiation between groups defending and seeking to expand their interpretation of cultural reality. ${ }^{13}$

Increasingly communication and media studies see communication as closely linked with creating, debating, changing and conserving cultural meanings. Media studies are more and more cultural studies and a form of humanistic studies.

„Aetatis Novae" reflects and extends this contemporary understanding of communication when it speaks of "Media at the service of persons and cultures" (7), „Media at the service of dialogue with the world“ and its cultures (8), and when it places as one of the most important pastoral priorities, the „Defense of human cultures" (No 16). The emphasis on the close relation of communication and culture-and the defense of cultures - expresses especially a concern of the "New Churches" in the "New Nations". Unfortunately, in the Appendix, offering „Elements of a Pastoral Plan for Social Communication“ this emphasis on a communion, cultural conception of communication tends to evaporate and we are back in a more linear, transport and technology dominated conception of communication.

\section{The Growing Concern With the Church's „Internal“, Pastoral Com- munication and Evangelization}

$C P$ deals very largely with the formation of the public, societal institutions of mass media. In this, it takes its cue from the Vatican II Pastoral Constitution on the Church in the Modern World, „Gaudium et spes“, which encouraged Catholics to come out of a ghetto and to build a secular society in the image of the gospel. $C P$ was also concerned with an organizational and leadership structure that could plan pastoral communication in the church, but it did not spell this out in any great detail. With its emphasis on social communications, $C P$ tended to reinforce the prevalent view that "communications" mean working in the mass media and becoming assimilated into a highly professional, technical worId quite distant from the ordinary pastoral life of the Church.

Most bishops or bishops conferences could feel that they had implemented $C P$ if they establish a communication office that takes care of public relations with the media, work with the media in transmitting the Sunday liturgy and a few other programs, and perhaps provide the faithful with some guidelines for the prudent, moral use of cinema and television. The church's internal informa- 
tion and communication needs are generally taken care of by Catholic newspapers that often have little coordination with the "communications office" or with other pastoral planning.

Most of the "communications" activities of the church are so marginal to the life of the ordinary parish that the pastors and parishioners would hardly be aware that they exist. The pastoral communication at the diocesan and parish level continue on in its traditional, centuries-old patterns as if the media did not exist at all. At best, the media are looked on as ,just entertainment" that might be vaguely damaging to religious and moral values but still something quite tangential to the spiritual growth of Catholics. Most pastors have had only the vaguest notion of how much their parishioners use film, television, popular music, radio and the press, and there is even less awareness of how this enters into the construction of values of the people.

Pastoral planning in the diocese and various renewal programs has been carried on with little reference to the media. Some audiovisual aids might be used in catechetics, but this is generally simply illustrative of the material transmitted essentially by oral and print communication. If pastors are aware at all that the diocese or episcopal conference sponsors broadcasts, they rarely make any encouraging references to these religious broadcasts or attempt to integrate these into the pastoral care and education of the parishioners. For example, if there is a broadcast mass for the shut-ins and the elderly ... or for others who were interested ... the parish might make sure that communion is taken to these people but the broadcast mass is not made an integral part of care of the sick and the elderly.

Preparation of future priests and other pastoral personnel is generally carried on with no reference to the arrival of the mass-mediated culture that $C P$ has proclaimed. Most seminaries have now introduced intensive clinical-psychological pastoral training, and there are pastoral practice programs. But seminarians and young religious are often restricted in their use of mass media with little or no introduction to the cultural and pastoral significance of the media. Seminarians are sometimes given a two weeks immersion in radio and TV studios-but too often this is simply a reinforcement of the view that the world of media is a complicated technical affair that has little to do with the loving interpersonal pastoral relationship that seems central to the pastoral vocation. Where there is some introduction to the imaginative world of the mass media, this has almost no relationship to theological education. In fact, with the influence of the recent great systematic theologians, theological education since Vatican II often has tended to become more analytical and even more remote from pastoral communication. Although skill in giving interesting homilies is important in the face of the extremely entertaining fare of mass media, the level of training in homiletics, public speaking and dramatics in many seminaries has declined. The tradition of dramatic, imaginative preaching that was once evident in the popular missions, preached retreats and motivational talks is less strong. Training in group communication-so important for a church increasingly centered around prayer and discussion-is almost non-existent. ${ }^{14}$ 
There would probably be less concern about the internal communication of the church were it not for the fact of other evidence of crisis, especially in media-saturated countries: shrinking attendance at Mass and other parish activities, especially among the young; decline of priests and other dedicated religious personnel to staff the religious education process on which the communication of the faith from one generation to another has so largely depended; the evident decline in religious knowledge and commitment to Catholic moral norms among people who identify themselves as Catholics; etc.

A further shock to Catholic leadership regarding the internal communication in the Church has come from information regarding the large number of Catholics who are faithful listeners/viewers of the sectarian televangelists. Although there is little evidence that converts are made through television broadcasts, many Catholics find in these televangelists significant religious inspiration that they cannot find in their own church. It is clear that the evangelical, fundamentalist sects are growing rapidly and attracting many Catholics. There is evidence that the religious broadcasts are one of the integral parts of the expansion movements of evangelical sects, especially in giving this religious option a public visible presence that adherents can identify with. ${ }^{15}$

While Catholicism has historically been quick to use media for its pastoral communication-for example, the introduction of the catechism and other printed materials at the time of the sixteenth century reformation-there is a general immobility and slowness to incorporate the contemporary media.

Finally, in cases where the Church has made expensive investments in diocesan media production centers, diocesan broadcasting, national satellite telecommunication systems, or other new technologies, often this is not well used in pastoral communication. At times media specialists have urged church leadership to get involved in media technology "while there is still time in the race to claim media territory", but there has been little previous planning as to how this is to be integrated into existing pastoral activities.

All this has been pushing church leaders and leaders in the church's communication apostolates toward the priority of planning a renovation of the church's pastoral communication and toward the careful integration of mediated communication with every aspect of pastoral activity.

\section{Willingness to Take a More Independent, Critical Stance regarding Media Institutions}

"Aetatis Novae“ very prominently mentions in Part III (Nos 12-15), „Current Challenges", "the need for a critical evaluation" of the media, the fact that "mass media at times exacerbates individual and social problems which stand in the way of human solidarity and the integral human development of the human person", the fact of "the unjust exclusion of some groups and classes from access to the means of communication", ,the systematic abridgement of the fundamental right to information", and "the widespread domination of media by economic, social and political elites". 
What "Aetatis Novae" tends to stress, much more than $C P$, is that these problems are not just momentary abuses but systematic problems deeply imbedded in the fundamental organization of the media today. One does find in "Aetatis Novae" the continuing hope that in some degree at least media can be at the service of persons and cultures, and at the service of human community and progress. One can be grateful to $C P$ for overcoming a defensive, negative attitude toward media that characterized the Church's stance in the nineteenth and early twentieth centuries. The conclusion of "Aetatis Novae" reaffirms the view that the media in accordance with God's providential design can unite men in brotherhood, but the cooperation with God's design now includes a decidely critical evaluation and reform.

At the time that $C P$ was being formulated, the media were more clearly public service institutions or regulated by public service guidelines. The new concept of international development had enormous confidence that simply by technology transfer and rapid communication of knowledge through the mass media, many of the problems of the world could be quickly eliminated. Media studies were largely at the service of the press and broadcasting institutionswhat is today referred to as "administrative research". There was some discontent with the tendency to present too much violent and explicit sexual material, but these were problems that the public and, specifically, the churches thought they could easily resolve. $C P$ reflects this very optimistic confidence in the public service motives of the media and rarely is there a warning about abuses.

Over the last twenty years, media studies and the public in general have developed much higher expectations of the media and are demanding a much broader range of public communication possibilities. For example, the public wants more participation in defining media content and in the formulation of media policy. There is a demand for better quality media for different groups such as children, the elderly, the poor and the disadvantaged.

At the same time, with the addition of many new communication technologies, media have become ever more central and indispensable in human life. As has been noted above, agencies of social power cannot afford to neglect strengthening control in these areas and have greatly perfected their ability to exert influence through the mass media. We have only to look at how political elections have changed with today's public relations, advertising and image creation capacities. The development of the transnational corporation has made it possible to orchestrate a single marketing or public relations campaign simultaneously throughout the world over the heads of local governments.

A tradition of critical media studies has become far more developed over the last twenty years, and the public has been increasingly suspicious of the media's own self-serving ideologies. The critical stance regarding the media has been especially developed in the New Nations and in the New Churches. In Latin America, the Philippines, India and in those parts of Africa where Catholics are a more significant and confident body, the Church has developed a close identification with the poor, the marginal and with those who suffer evident injustices. It is in these parts of the world that there has developed a theology 
much more concerned with "the option for the poor", the defense of human rights, the defense of cultural authenticity, and promoting participation in all aspects of the history and culture of the countries.

When one reads „Aetatis Novae" one finds many themes that are commonplace in the statements of bishop's conferences and in consensus documents of Christian communicators in the nations of the South. Again, in a more critical stance, this pastoral instruction reflects the contribution of the churches of the new nations to the universal church.

\section{The Centrality of Theological Reflection on Communications, Media Institutions and the Churches Communication Activities}

In the last twenty years, one finds an increasing interest in the clarification of theological criteria with regard to communications. This has been stimulated by a number of factors:

a) The development of pastoral theologies and theological reflection on pastoral practice that directly involves new approaches in communication. Pastoral planning and the formulation of major pastoral documents such as the documents of Medellin and Puebla published by the Latin American Episcopal Conference have incorporated sections on pastoral communications that are given an overall theological foundation. The communication activities of the Church in Latin America are given a theological foundation in the keynotes themes of "communion and participation" in the document of Puebla.

b) As different uses of media become more central to pastoral approaches of the churches, there is much more controversy about whether a particular use of broadcasting or group communication can be justified by gospel norms and the theological traditions. Inevitably, these debates are driven back to theological criteria.

c) The critique of communication institutions in the contemporary world and the critique of mass-mediated cultures has also been forced to find theological foundations.

d) The attempts to introduce a new communication training in seminaries has also demanded a theological reflection, in part to establish criteria of selection of what to teach in seminaries and in part to build integrating links with the rest of the theological education.

e) Finally, with the establishment of advanced degree programs in communication for Christian communicators, especially those who will be working within the Church's communication and media activities, it has been necessary to introduce courses of theological reflection on communication and pastoral communication with a foundation in the theologies of communication. This is especially important for the formation of future teachers of pastoral communication in seminaries.

In a few instances, such as the Centre for the Interdisciplinary Study of Communication at the Gregorian University in Rome, it is now possible to obtain a licentiate or doctorate in theology with a specialization in theology and com- 
munication. This Centre at the Gregorian has sponsored, a bi-annual conference on Theology and Communication and is publishing a series of books based on these conferences.

In spite of the many conferences, seminars and books that deal with theology and communication, it is still difficult to find books which provide an integrating synthesis on the theology that are widely read or accepted. One of the best syntheses of Catholic theology of communication is still that found in Part I of $C P$. „Aetatis Novae“ simply restated some of the main theological points of $C P$ without too much significant addition.

\section{Concluding Remarks}

A central message of „Aetatis Novae“ is that the recent rapid advances in communication technology and new understandings of communication have yet to become an integral part of the life of the Church in the way that rhetoric, the book, the icon and architecture have become central to announcing the good news and subsequently in faith expression, pastoral action and theological reflection. Since the Second Vatican Council, "pastoral planning" has become a much more central "language" for evangelization and renewal. Often, it is in the recognition of a certain crisis of communication-the realization that "we simply are not reaching the people" - and the decision to embark on a "new evangelization" that there is a reorganization of communication and use of media in the Church.

Thus, the recommendation that the local churches focus their energies on a pastoral plan for social communications has deep and far reaching implications for the kind of renewal that the Second Vatican Council tried to set in motion. It is in the consultation, reflection and debate regarding an adequate plan that the local churches are most likely to incorporate into their pastoral action not only the changes emerging over the last twenty years but some of the enduring guidelines of $C P$.

If one were to sound a note of caution regarding the kind guidelines that "Aetatis Novae" recommends for a pastoral plan for social communications, it is the lack of emphasis on a spirituality of faith communication and the lack of direct emphasis on grounding this planning in a process of theological reflection during all stages of the conception and implementation of such a plan. One of the most important points in the plan is that of "Spiritual Formation and Pastoral Care" (No 29), but nothing is said about theological reflection.

When Cardinal Martini begins his reflection on the mass media and its implications for the life of faith in Il Lembo del Mantello (The Hem of the Garment), he opens with „A little digression on the 'theological' significance of my television set." In referring to his television set-and the mass media in general-as the "hem of the Lord's garment" in which something of the miraculous power of Christ flows, Martini links television not just to theological meaning but to the simple faith of a woman who seeks healing from Jesus. Cardinal Martini is appealing not just to our need for rationalized planning but to our faith 
and deepening prayer. Likewise, when Cardinal Martini set the foundations for pastoral planning of communications in his huge archdiocese, he started with another biblically-guided, faith-inspired document of theological reflection, „Effata, 'Apriti'“, „Effata, let the mouth and ears be opened“.

Anmerkungen:

1 "Aetatis Novae, No 1.

2 A summary discussion of changes in the fundamental paradigm of communication is found in the Journal of Communication, Vol 33, No 3 (October 1983), special issue entitled, "Ferment in the Field".

3 Martin, Bernice. The Sociology of Contemporary Cultural Change. New York: St. Martin's Press, 1981.

4 A good review of the difficulties of public service broadcasting and the tendency to exclude religious programming is found in Communication Research Trends, Vol 8 (1987), Nos 3 \& 4, "The Crisis in Public Service Broadcasting" and "Citizens and Consumers: Religious Broadcasting Between Public Service and Deregulation“.

5 Jensen, Joli. Redeeming Modernity: Contradictions in Media Criticism. Newbury Park: Sage Publications. This book provides a striking analysis of the fallacy of blaming the media for many social ills.

6 Cf James Carey's comparison of European and American conceptions of communication, "Mass Communication Research and Cultural Studies: an American View" in Mass Communication and Society. Ed. by James Curran, Michael Gurevitch and Janet Woollacott. London: Edward Arnold in association with Open University Press. Pp 193-210.

7 Rogers, Everett M. and D. Lawrence Kincaid. Communication Networks: Toward a New Paradigm for Research. New York: The Free Press, A Division of Macmillan Publishing Co., 1981.

8 Carey, op.cit.

9 Katz, Elihu and Daniel Dayan. „Media Events: On the Experience of Not Being There", Religion, Vol 15 (July, 1985), pp. 305-314.

10. Real, Michael. "Ritual Analysis“ in Supermedia: A Cultural StudiesApproach. Newbury Park: Sage Publications, 1989. pp 222-249.

11 Newcomb, Horace and Paul M. Hirsch. „Television as a Cultural Forum“ in Interpreting Television: Current Research Perspectives. Ed. by Willard D. Rowland, Jr and Bruce Watkins. Newbury Park: Sage Publications. Pp 58-73.

12 Turner, Victor. From Ritual to Theatre: The Human Seriousness of Play. New York: Performing Arts Journal Publications.

13 González, Jorge, „Los Frentes Culturales“, Estudios sobre las culturas contemporaneas, Vol 1 (Mayo, 1987), No 3, pp 5-44.

14 There are many exceptions to these observations about the teaching of communications in seminaries, but the systematic research which I have carried on over the last ten years, especially a three nation study of Chile in Latin America, Nigeria in Africa and the Philippines in Asia, leads to these conclusions. From time to time a particular seminary may, under the encouragement of the local Catholic communication office, bring in a very fine communication/media teacher, but this often is not sustained. Communication education has not become a regular, standard subject matter for which seminaries feel they must train and/or hire competent teachers.

15 Horsfield, Peter, Religious Television: The American Experience. New York: Longman, Inc. 1984. p. 131. Hoover, Stewart, Mass Media Religion: The Social Sources of the Electronic Cburch. Newbury Park: Sage Publications. Chs $9 \& 10$. 


\section{ZUSAMMENFASSUNG}

Anläßlich des Erscheinens der neuen Pastoralinstruktion "'Aetatis Novae' zur sozialen Kommunikation zwanzig Jahre nach Communio et progressio" beschäftigt sich der vorliegende Artikel mit den Entwicklungstendenzen im kirchlichen Nachdenken über „soziale Kommunikation“ und Massenmedien in den letzten zwei Jahrzehnten.

Nachdem "Communio et progressio" 1971 in einer überwiegend optimistischen und zukunftsorientierten Perspektive - ganz im Sinne von Gaudium et spes - allgemeine Grundaussagen über den Wert der Medien sozialer Kommunikation für Kirche und Gesellschaft formulierte und ihre Bedeutung für eine fortschreitende Verständigung unter den Völkern betonte, spiegelt sich in „Aetatis Novae" die Erfahrung, daß auf dem Feld konkreter Medienpraxis auf diözesaner und pfarrlicher Ebene - im Vergleich zu anderen Denominationen (wie z. B. den "Teleevangelisten"protestantischer Sekten, die sich auch bei vielen Katholiken großer Beliebtheit erfreuen) - bisher relativ wenig geschehen ist. Dementsprechend bilden für den Autor auch die als „Anhang“ zu "Aetatis Novae“ vorgelegten und vor allem an die Ortskirchen adressierten „Elemente eines $\mathrm{Pa}$ storalplans für soziale Kommunikation“ (AN 23-33) die zentrale Botschaft dieser Instruktion. Auch wenn die neuen Entwicklungen der letzten 20 Jahre (vor allem die veränderten technologischen, politisch-ökonomischen und kulturellen Dimensionen der sozialen Kommunikation und die wachsende Bedeutung der ,jungen Kirchen“ Afrikas, Asiens und Lateinamerikas mit ihrer zum Teil neuund andersartigen Wahrnehmung des Phänomens sozialer Kommunikation) dringend einer adäquaten theologischen Reflexion bedürfen, zeigt sich Aetatis Novae hier sehr zurückhaltend; vielleicht auch ein Anzeichen dafür, daß innerkirchlich gegenüber den aktuellen Herausforderungen noch keine konsensfähige Antwort gefunden wurde.

Der Autor identifiziert für die letzten 20 Jahre vor allem drei bedeutungsvolle Entwicklungslinien und Problemfelder:

1. In den späten 60er Jahren wurde das Feld sozialer Kommunikation weithin und fraglos mit dem in der Regel staatlich oder öffentlich-rechtlich organisierten System der Massenkommunikation identifiziert. Die Massenmedien standen in einer sozialen Verantwortung; sie galten als "vierte Gewalt" und "öffentliches Diskussionsforum" der Gesellschaft, in der auch religiösen Programmen ein selbstverständlicher Platz zukam (vgl. CeP, Teil 3 und 4). Während der 70er und 80er Jahre haben die tiefgreifenden Privatisierungs- und Deregulationsprozesse jedoch dazu geführt, daß dieses Ideal der Massenmedien als öffentliche Dienstleistungsbetriebe verloren ging und die neue Medien- und Kulturindustrie zusehends mit sozial- und kulturkritischen Anfragen konfrontiert wurde. Auch religiöse und pädagogische Programme haben durch die Privatisierungsprozesse ihren fraglosen Ort im Rundfunksystem verloren, so daß sich die Kirchen - wo sie nicht den (nur selten erfolgreichen) Kampf um die Erhaltung des öffentlichen Rundfunksystems unterstützten - genötigt sahen, jenseits der großen Massenanbieter (z. B. in Lokalprojekten) verstärkt tätig zu werden oder eigene Rundfunksysteme aufzubauen.

Zugleich entstanden in vielen Teilen der Dritten Welt neue kirchliche Initiativen, die im Sinne der „Option für die Armen" die arme und marginalisierte 
Bevölkerung in ihrem Bemühen unterstützten, eine Infrastruktur von Graswurzel-Organisationen aufzubauen, um die eigenen Rechte zu verteidigen und sich gegen Ungerechtigkeiten zur Wehr zu setzen. In diesem Umfeld entstanden neue, kleinere Formen kirchlicher Kommunikationsarbeit wie Lokalradio, Alternativzeitungen und Rundbriefe mit minimaler Auflage, Volks- und Straßentheater etc., die (jetzt freilich nicht mehr im Blick auf die "großen Medien“) den Idealen von $\mathrm{CeP}$ überraschend nahe kommen.

2. In den 60er und 70er Jahren herrschten noch mechanisch-statische Modelle von linearen "Medienwirkungen“ vor, die die Rezipienten primär als passive Opfer medialer Einflüsse wahrnahmen. Dagegen formulierte CeP bereits ein an "Gemeinschaft und Partizipation" orientiertes Modell öfentlicher Kommunikation, demzufolge sich Medieneinflüsse u. a. an gemeinsam geteilten Werthaltungen und personalen Interaktionen der Rezipienten brechen und neu zusammensetzen. Während dieses Modell - Kommunikation als vielschichtiger kultureller Prozeß der Bildung, Reflexion, Veränderung und Neukonstruktion einer gemeinsam geteilten Lebenswelt - in der Medienwirkungsforschung immer stärkere Bedeutung erlangt, orientieren sich viele kirchliche „Kommunikationsarbeiter" nach wie vor am alten linearen Wirkungsmodell und erschweren sich damit einen konstruktiven Zugang zu den vielgestaltigen Medienrealitäten. Auch "Aetatis Novae" bleibt hier ambivalent: zwar finden sich viele positive Aussagen gerade zur Bedeutung kultureller Identitätsformen (AN 7, 8, 16); der Pastoralplan fällt jedoch wieder in die alte instrumentalistische Sicht zurück.

3. Während sich die katholische Kirche z. B. im 16. Jahrhundert mit der Einführung von Katechismusbüchlein u. ä. sehr schnell die neue Technik der Massenkommunikation zu eigen machte, besteht gegenüber den heutigen Medientechnologien eine beträchtliche Immobilität. Zwar geschieht einerseits in teuren kirchlichen Rundfunkstudios und Produktionsstätten wichtige kirchliche „Kommunikationsarbeit“; andererseits sind diese Einrichtungen aber ebenso wie bischöfliche Kommunikationsbüros und Pressestellen kaum mit den gewöhnlichen pastoralen Aktivitäten der Kirche verbunden. Im normalen Alltag der Kirchengemeinden ebenso wie in der Priester- und Mitarbeiterausbildung kommt das Medienzeitalter kaum in den Blick. Es scheint hier vielfach, als ob Massenmedien noch gar nicht existieren würden.

Abschließend betont der Autor, daß „Aetatis Novae" im Vergleich zu CeP einerseits weiterführende Reflexionen über die theologische Bedeutung sozialer Kommunikation (hier ist CeP, 1. Teil, theologisch nach wie vor unüberholt) vermissen läßt, andererseits aber (gegenüber der oft naiv-optimistischen Sichtweise des 1971er Dokuments) die reiche Tradition kritischer Medienforschung aufnimmt, wie sie sich nicht zuletzt in den "neuen Nationen“ und „jungen Kirchen" (vgl. die Debatte um die Neue Weltinformations- und Kommunikationsordnung) ausgebildet hat.

\section{RÉSUMÉ}

20 ans après „Communio et progressio“, une nouvelle instruction pastorale vaticane concernant des questions de la communication sociale fut publiée. 
A cette occassion, l'article reflète des domaines de problémes importants dans la réflexion de l'eglise sur le questions de la communication de masse et il s'intéresse avant tout à trois tendances de développement:

1. Aux procès de privatisation des années 70 et 80 au cours desquels la position des médias en tant qu'entreprises du service public change profondément; mais aussi à la sensibilité croissante de „jeunes églises" de l'Asie, de l'Afrique et de l'Amerique Latine pour les "petites" formes de communication sociale comme la radio locale, les journaux alternatives et le théâtre de la rue;

2. au renvoi des anciens modèles linéaires de effets de médias en faveur d'un modèle plus différencié de l'interpénétration culturelle qui s'exprime seulement en partie en "Aetatis novae“;

3. au manque de relation entre le travail de communication professionnelle de l'église dans ses propres stations de radio et lieux de production et la vie quotidienne de paroisses et des groupes de l'église.

Au total, l'auteur remarque dans „Aetatis novae“ le manque d'une réflexion théologique fondamentale sur le phénomène de la communication sociale. Cependant, il juge la considération de éléments d'une recherche critique et distanciée des médias comme un progrès en la comparance à l'opinion parfois naive et optimiste de Communi et progressio.

\section{RESUMEN}

20 años después de "Communio et progressio" ha aparecido en 1992, con "Aetatis Novae“, una nueva instrucción pastoral del Vaticano referida al la comunicación social.

Con tal motivo, el artículo se refiere a importantes campos de la reflexión de la Iglesia en lo tocante a cuestiones de la comunicación de masas y se ocupa, sobre todo, de tres líneas de desarrollo.

1. De los procesos de privatización que en los años 70 y 80 cambiaron fundamentalmente el status de servicios públicos que tenían los medios; pero también de la creciente sensibilidad de las "iglesias jóvenes" de Asia, Africa y América Latina por las „pequeñas“ formas de comunicación social, como la radio local, los periódicos alternativos y los teatros callejeros, 2 . de la despedida de los antiguos modelos lineales de efectos en los medios, en favor de un modelo de interpretación cultural pluriestratual. Modelo que se expresa, sin embargo, sólo parcialmente en „aetatis Novae“ y 3. de la falta de comunicación entre „profesionales“ de la comunicación eclesial en sus propias emisiones e instalaciones y la vida cotidiana de parroquias y grupos eclesiales.

El autor echa de menos en "Aetatis Novae" una reflexión teológica fundamental del fenómeno de la comunicación social. Frente a la visión ingenuooptimista de Communio et progressio, valoriza, sin embargo, como progreso la toma en consideración de elementos de una investigación de los medios críticodistanciada. 